\title{
鉄筋の腐食分布がRCはり部材の 曲げ耐荷性状に及ぼす影響
}

\author{
斉藤 成彦 $1 \cdot$ 高橋 良輔 2 -檜貝 勇3 \\ 1正会員 山梨大学准教授 大学院医学工学総合研究部（干400-8511 甲府市武田4-3-11） \\ E-mail:ssaito@yamanashi.ac.jp \\ 2正会員 山梨大学助教 大学院医学工学総合研究部（干400-8511 甲府市武田4-3-11） \\ E-mail:rtakahashi@yamanashi.ac.jp \\ 3 正会員 山梨大学教授 大学院医学工学総合研究部（干400-8511 甲府市武田4-3-11） \\ E-mail:higai@yamanashi.ac.jp
}

\begin{abstract}
鉄竻腐食の生じた構造物の維持管理では，点検より得られる外観変状からグレーディングを行い，構造 性能を半定量的に評価しているのが現状である。また，鉄筋の腐食は構造物中で空間的なばらつきを有し ており，鉄筋の腐食程度と耐荷性能との関係は明確に評価されていない。非線形構造解析を利用し，構造 性能を定量的に評価することができれば，より合理的な対策の実施が可能になるものと考えられる. 本研 究では，鉄筋腐食の生じたRCはり部材を対象とし，鉄筇の腐食分布が而荷性状に与える影響について解 析的に検討を行った. RCはり部材の曲げ而荷性状は最小断面積と付着劣化状態に大きく依存し, 腐食分 布特性が与えられれば，構造解析により耐荷力のばらつきの範囲を概ね評価できることを示した.
\end{abstract}

Key Words : RC beam, flexural capacity, corrosion distribution, rigid-body-spring model

\section{1. はじめに}

コンクリート構造物の維持管理とは, 供用期間を通じ て構造物が保有すべき要求性能を許容範囲内に維持する ために，点検や劣化予測を行い，その結果を評価・判定 し，対策を講じることである. 土木学会コンクリート標 準示方書 [維持管理編］では，維持管理の対象となる要 求性能に対して必要な点検方法が示されているが，現有 而渮性能のような構造性能の評価は必ずしも定量的なも のとなっていない1). 例えば，塩害に対する維持管理で は，塩化物イオン濃度分布，ひび割れ，錆汁，エフロレ ッセンスなどの各種測定項目とそれに対応した評価項目 が示されている. しかしながら，これらの測定結果から 構造物の耐荷性能を直接評価することは難しく, 点検に より把握した外観変状からグレーディングを行い，構造 物の性能低下を半定量的に評価しているのが現状である. したがって, 構造物の点検結果から構造性能を定量的に 把握する手段が確立されれば，より合理的な対策が実施 できるものと期待される.

材料の劣化したコンクリート構造物の性能を定量的に 評価する方法として, 非線形構造解析の適用が考えられ
る. 塩害などにより材料劣化の生じた構造物に対しては, 詳細点検により鉄筋の腐食状態に関する情報が得られれ ば，それを入力值とした非線形解析によって現有する構 造性能を精度良く把握できる可能性がある. しかしなが ら，構造物中の鉄筋の腐食程度は空間的なばらつきを有 しており，供用中の構造物に対して鉄筋の空間的な腐食 分布を正確に把握することは難しい。したがって，限ら れた情報を用いて構造解析を実施し, 構造性能を評価す るためには，鉄筋腐食のばらつきが構造性能にどのよう な影響を与えるのか, あらかじめ十分に認識しておく必 要がある. 既往の研究2),3,4,5,5) では, 鉄筋腐食の生じた部 材の耐荷性状を非線形解析により評価可能であることが 示されているが，腐食のばらつきが耐荷性状に及ぼす影 響についてはほとんど検討が行われていない。

一方，鉄筋腐食の生じたコンクリート部材の構造性能 に関する実験的研究が数多く実施されており ${ }^{77,89}$, 9) 腐食 の程度が大きくなるにつれ耐荷性能が低下寸ることが確 認されているが，腐食程度と耐荷性能との関係は研究に よって異なっている. その最大の要因は, 電食・曝露な どの劣化促進手法を問わず，供試体内の鉄筋の腐食程度 にばらつきがあるためであり，腐食のばらつきが而荷性 


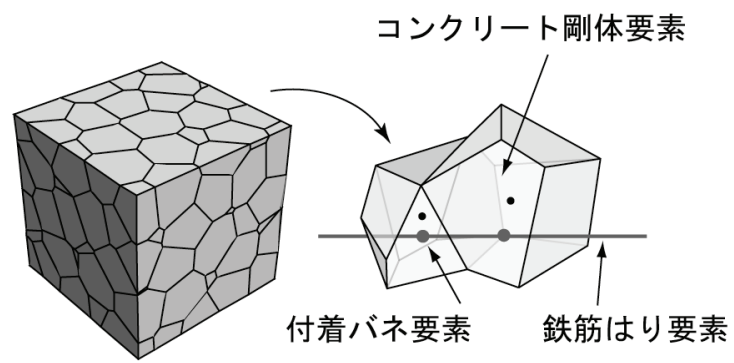

図-1＼cjkstart鉄筋コンクリートの離散化

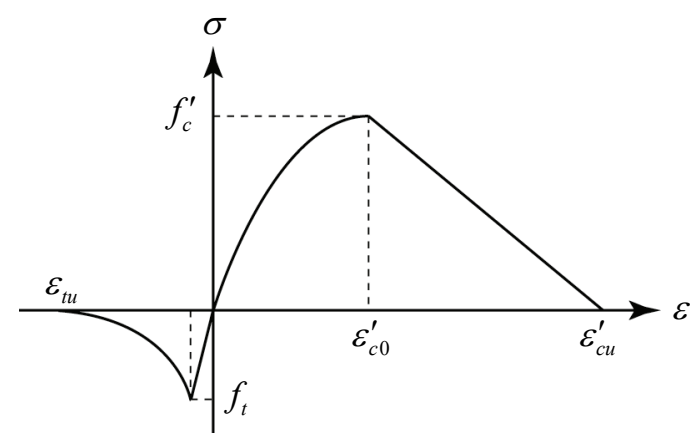

図-2 コンクリートの応力-ひずみ関係

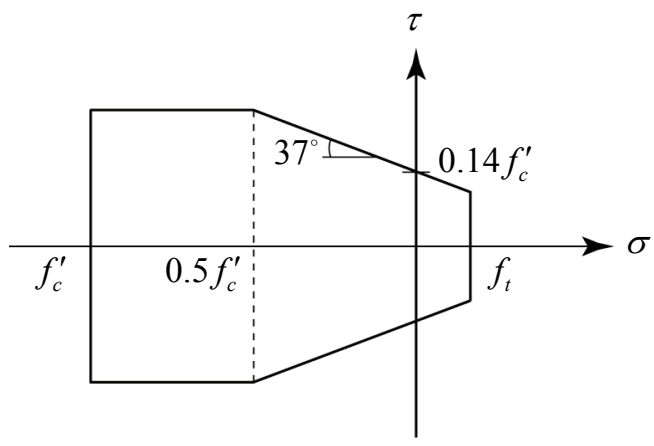

図-3 モール・クーロン型破壊条件

状に及ぼす影響については明らかにされていない.

そこで本論では，曲げ破壊する鉄筋コンクリートはり 部材の非線形構造解析を行い，鉄筋の腐食分布が而荷性 状に及ぼす影響について検討を行った。

\section{2. 解析手法}

\section{(1) 剛体バネモデル}

本研究では，非線形構造解析手法に剛体バネモデルを

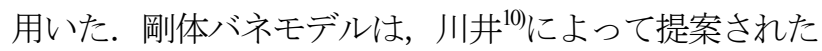
離散型の解析手法であり，コンクリートのひび割れのよ うな材料の不連続現象を比較的容易に表現することがで きる. 既往の研究 ${ }^{11) 12}$ により，剛体バネモデルのRC部材 解析への適用が確認されており， RC部材の破壊挙動を 比較的精度良く評価することが可能である。

図-1のように，コンクリートはVoronoi分割を用いて任 意多面体要素に分割し，ひび割れの要素分割依存性を低

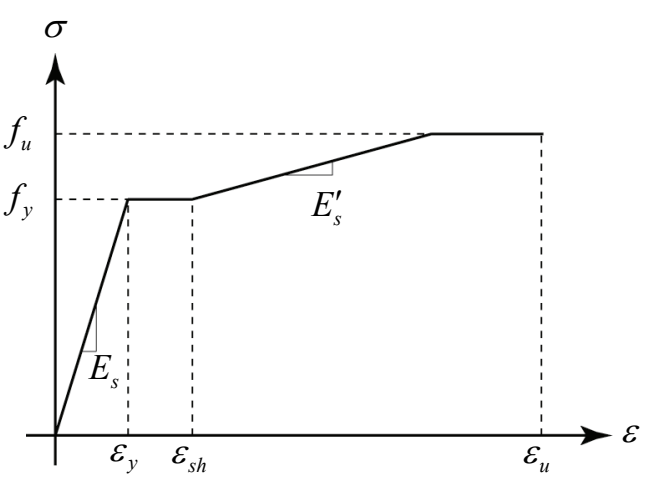

図-4 鉄筋の応力ーひずみ関係

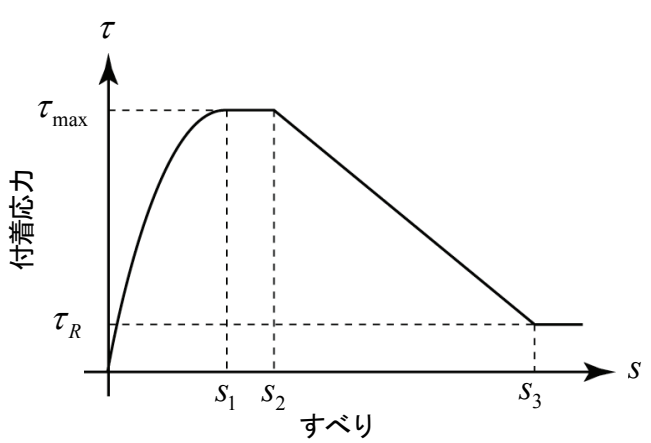

図-5 付着応力-す心゙り関係

減した。各剛体要素は6自由度を有し，コンクリートの 非線形挙動は剛体要素間に配置した重直バネとせん断バ ネにより表現した。垂直バネにはコンクリートの圧縮・ 引張挙動をモデル化し，図-2に示される応力ーひずみ関 係を適用した，圧縮応力下に対しては，圧縮強度 $f_{c}^{\prime}$ に 達するまで放物線で仮定し，その後は圧縮破壊エネルギ 一で定義される終局ひずみ $\varepsilon_{c u}^{\prime}$ に達するまで線形で軟化 するように仮定した，引張応力下に対しては，引張強度 $f_{t}$ に達するまで線形で仮定し, その後は破壊エネルギ 一で定義される終局ひずみ $\varepsilon_{t u}$ に達するまで指数曲線で 軟化をモデル化した. せん断バネは，コンクリートのせ ん断伝達機構を表し，せん断強度は図-3で表されるモー ル・クーロン型の破壊条件により決定した．構成モデル

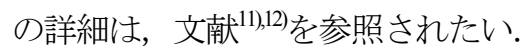

\section{(2) 鉄筋のモデル化}

図-1に示すように，鉄筋ははり要素を用いて離散的に モデル化した。それぞれの鉄筋は一連のはり要素により 構成され，はり要素の節点において付着バネ要素を介し てコンクリート剛体要素に接合される.

鉄筋の材料モデルには，図-4で表される応力ーひずみ 関係を適用した。図中の $E_{s}$ は弾性係数， $E_{s}^{\prime}$ は硬化後の 剛性 $\left(E_{s}^{\prime}=0.01 E_{s}\right), f_{y}$ は降伏強度， $f_{u}$ は引張強度 $\left(f_{u}=1.5 f_{y}\right) ， \varepsilon_{y}$ は降伏強度時のひずみ， $\varepsilon_{s h}$ は硬化開 始時のひずみ $\left(\varepsilon_{s h}=0.01\right), \varepsilon_{u}$ は破断時のひずみ $\left(\varepsilon_{u}=\right.$ 0.2) である. 


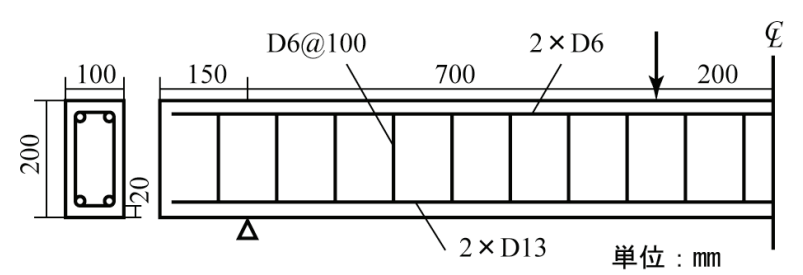

図-6 解析対象供試体概要 ${ }^{14)}$

付着バネ要素に対しては，図-5で表される付着応力すべり関係を適用し，鉄筋とコンクリート間の付着す心゙ り挙動をモデル化した. かぶりの比較的小さいはり部材 に対する付着強度 $\tau_{\text {max }}$ は, 実験結果を参考に島式より求 まる付着強度の $40 \%$ に低減した ${ }^{13)}$. 図中のパラメータ は，それぞれ $\tau_{R}=0.01 \tau_{\text {max }}, s_{1}=0.15 \mathrm{~mm}, s_{2}=0.4 \mathrm{~mm}$, $s_{3}=0.8 \mathrm{~mm}$ とした.

\section{(3) 鉄筋腐食のモデル化}

鉄筋腐食がRC部材の耐荷性能に及ぼす影響を数值解 析により評価する場合には，腐食による鉄筋断面積の減 少，鉄筋の腐食膨張に伴うコンクリートのひび割れ，腐 食膨張による付着特性の変化といった, 材料の劣化状態 を考慮する必要がある. 有限要素法を利用した既往の研 究2)では，腐食した鉄筋の材料特性を変化させて解析を 行った例がある。これは，腐食程度のばらつきをある領 域（要素長さ）で平均的に扱うため, 見かけの弾性係数, 降伏強度, および伸び性能が小さくなることを考慮した ものである.

本研究では, 鉄筋軸方向に沿った腐食のばらつきその ものをモデル化し，その影響について検討を行った. 腐 食した鉄筋は，質量減少率 (断面減少率) に従って鉄筋 要素の断面積を減少させ，材料モデルには健全な鉄筋と 同じものを用いた．鉄筋の軸方向に沿って発生する腐食 ひび割れの影響は付着強度を低下させることにより考慮 し，腐食ひび割れそのものはモデル化せず，コンクリー トの材料特性は健全なままとした。これは，鉄筋軸に沿 うひび割れは，鉄筋に直交する曲げひび割れ等への影響 が少ないものと考えたためである．ただし，腐食膨張に よるひび割れの影響を考慮した解析例のもあることから， 鉄筋腐食によるコンクリートの損傷がどの程度の影響を 及ぼすかについては今後の検討課題である。腐食した鉄 筋とコンクリート間の付着特性は, JCIコンクリート構 造物のリハビリテーション委員会によって提案された実 験回帰式である次式》を用いて, 質量減少率に従って付 着強度を低減することでモデル化した.

$$
\frac{\tau_{b}}{\tau_{b 0}}=\exp (-0.0607 C)
$$

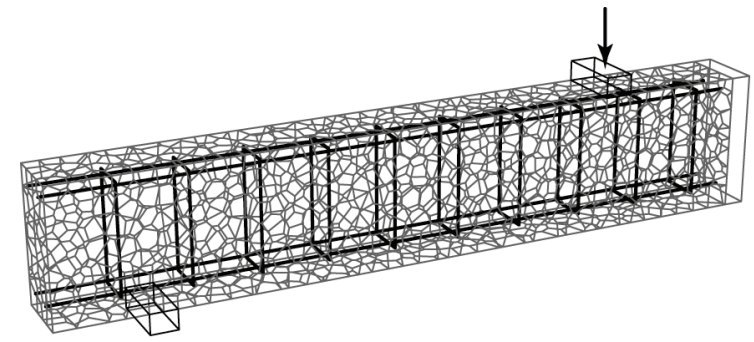

図-7 解析モデル

ここに， $\tau_{b} / \tau_{b 0}$ は付着強度比，C は質量減少率（\%) で ある。

\section{3. 腐食分布のモデル化が曲げ破壊性状に及ぼす 影響}

\section{(1) 解析概要}

本章では，鉄筋の軸方向に沿った腐食のばらつき（腐 食分布）のモデル化の違いが，RCはりの曲げ破壊性状 に及ぼす影響について検討を行った。

解析対象は，鉄道総研で実験の行われた図-6に示され るRCはり ${ }^{14}$ とした. 実験供試体は，引張鉄筋の平均質量 減少率が $0 \%$ か $44 \%$ の範囲で，電食により全ての鉄筋 を腐食させている. 図-7に解析モデルを示す．計算労力 の低減のため, 対称性を考慮してはりの $1 / 2$ をデル化 し，すべての鉄筋をはり要素により離散的にモデル化し た. 前述のとおり, 軸方向鉄筋の腐食は仮定する腐食分 布に従って鉄筋要素の断面積を減少させることによりモ デル化し，鉄筋とコンクリート間の付着強度の低下を考 慮した. 実験では, 供試体端部で軸方向鉄筋にフックを 設けているが，解析ではフックがないものとして計算を 行った.

コンクリート標準示方書 ${ }^{15}$ に基づく健全な実験供試体 の曲げ耐力の算定值は $21 \mathrm{kN}$ ，せん断耐力は $58 \mathrm{kN}$ であり， 十分なせん断耐力を有している. 実験におけるせん断補 強鉄筋の腐食量は報告されていないが，一般に，軸方向 鉄筋の外側に配置され比較的鉄筋径の細いせん断補强鉄 筋は，軸方向鉄筋に比べて腐食量が大きいことが考えら れる. しかしながら，本供試体ではせん断補強鉄筋がな い場合でも曲け破壊型となるため，せん断補強鉄筋は軸 方向鉄筋の平均質量減少率による一様な腐食が生じてい るものとして解析を行った.

実験におけるコンクリートの圧縮強度は29.8〜 $42.3 \mathrm{~N} / \mathrm{mm}^{2}$ の範囲であるが，解析では比較のため全ての 供試体で $40 \mathrm{~N} / \mathrm{mm}^{2}$ とした。 また，鉄筋の材料定数には実 測值を用い，降伏強度はD13鉄筋が $366 \mathrm{~N} / \mathrm{mm}^{2} ， \mathrm{D} 6$ 鉄筋 が355 N/mm²とした。 


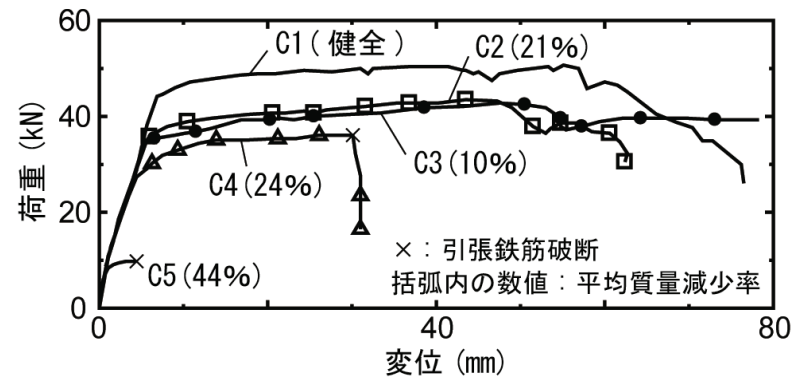

図-8 荷重-変位関係 (実験 $\left.{ }^{14}\right)$

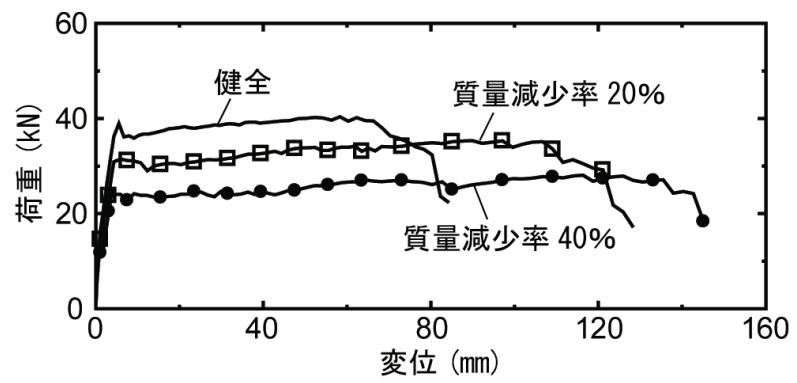

図-9 荷重-変位関係（解析：一様腐食）

\section{(2) 一様腐食を仮定した解析}

鉄筋腐食の生じたRCはり部材の基本的な耐荷性状を 評価するために，鉄筋軸方向の腐食のばらつきを無視し， 一様な腐食を仮定した解析を行った，質量減少率は，供 試体内の全ての鉄筋に対して0\%（健全），20\%，およ び40\%とした．式(1)により算出される腐食した鉄筋の付 着強度比は，質量減少率 $20 \%$ のもので約 $0.3 ， 40 \%$ のの で約0.09に低下することになる.

実験より得られた荷重-変位関係を図-8に，解析結果 を図-9に示す。健全な供試体に対する実験結果と解析結 果はともに，引張鉄筋の降伏後に変形が増大し，等曲げ モーメント区間の圧縮縁コンクリートの圧壊により荷重 が低下した．解析は耐力を若干過小評価しているが，耐 荷性状をよく再現できている．コンクリート標準示方書 に基づき算出された最大荷重は42kNであり，解析での

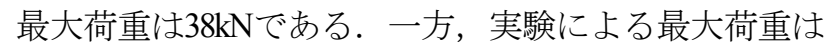
$50 \mathrm{kN}$ であり，解析や理論值に比べて大きな值となって いるが，これは供試体寸法が比較的小さいため，支点に よる拘束の影響などが大きく現れたものと考えられる.

解析における鉄筋腐食の生じた供試体は，質量減少率 の増加に伴って降伏荷重および最大荷重が低下するが, 低鉄筋比となるため，変形性能は増大することが確認で きる. 図-10に，解析より得られた降伏荷重時のひび割 れ性状を示す。図より, 質量減少率の増加に伴い付着強 度が低下するため，曲げひび割れの分散性が低下してい ることが確認でき，実験で観察されたひび割れ性状とも よく対応している.

実験は80mm程度の変位までしか提示されていないが, 平均質量減少率が10\%であるC3供試体は，解析と同様に
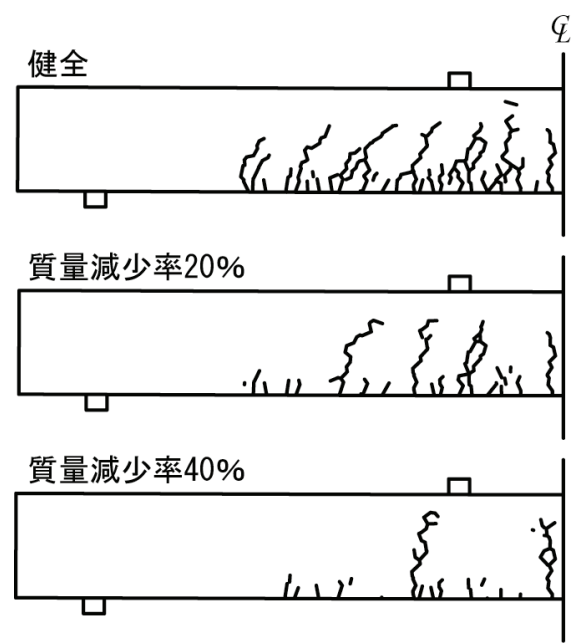

図-10 降伏時のひび割れ性状（解析：一様腐食）

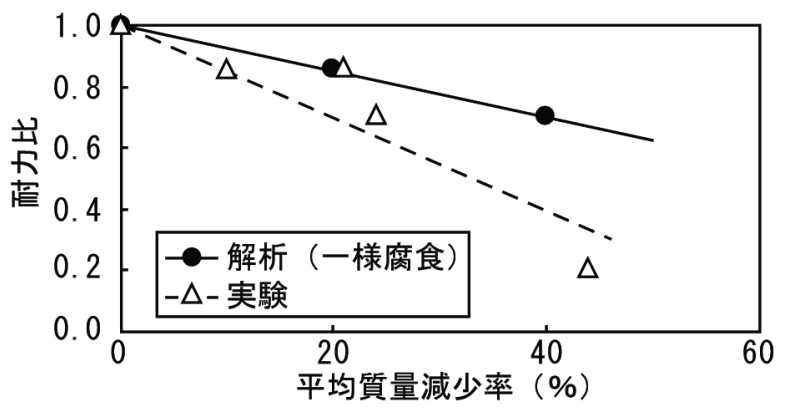

図-11 曲げ耐力比と平均質量減少率

健全な供試体に比べて変形性能が増大している. しかし ながら，平均質量減少率の比較的大きいC2, C4, C5 供 試体は変形性能が低下しており，鉄筋の破断を伴うもの も見られる．これは，実際の鉄筋の腐食が鉄筋軸方向に 沿って一様ではなく, 局所的な腐食が而荷性状に大きな 影響を及ぼしていることを示している.

図-11に，曲げ耐力比と平均質量減少率の関係を示す. 耐力比は，実験，解析ともに，健全な供試体の耐力を 1.0 とした. 図中の線分はそれぞれ直線回帰したもので ある. 一様腐食を仮定した解析結果は，コンクリート標 準示方書に基づいた曲げ而力の算定の際に，単純に鉄筋 断面積の減少を考慮して求めた算定值とほぼ同様の低下 率を示すが，平均質量減少率が増加するほど実験結果を 大幅に過大評価する傾向にある。これは，前述のとおり 実際の鉄筋の局所的な腐食が而力に大きな影響を及ぼし ているためであり，鉄筋腐食の生じたRC部材の耐力を 精度良く評価するためには，鉄筋腐食のばらつきを考慮 した評価を行う必要がある.

\section{(3) 腐食のばらつきを考慮した解析}

図-12は，実験で最も平均質量減少率の大きかったC5 供試体に対し，載荷試験後の供試体から採取した鉄筋の 断面積分布を3Dスキャナにより計測した結果である ${ }^{14)}$. 


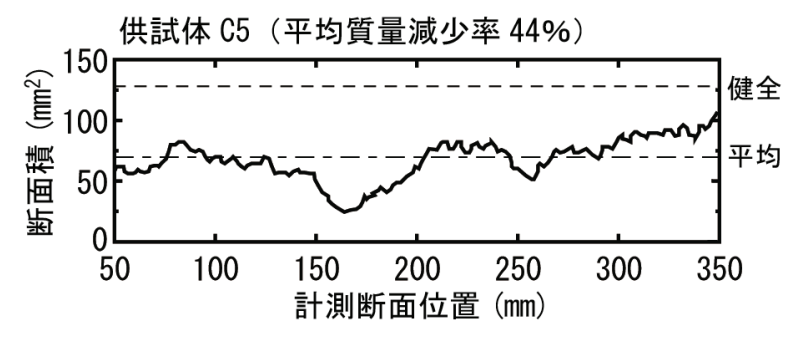

(a) 断面積の軸方向分布

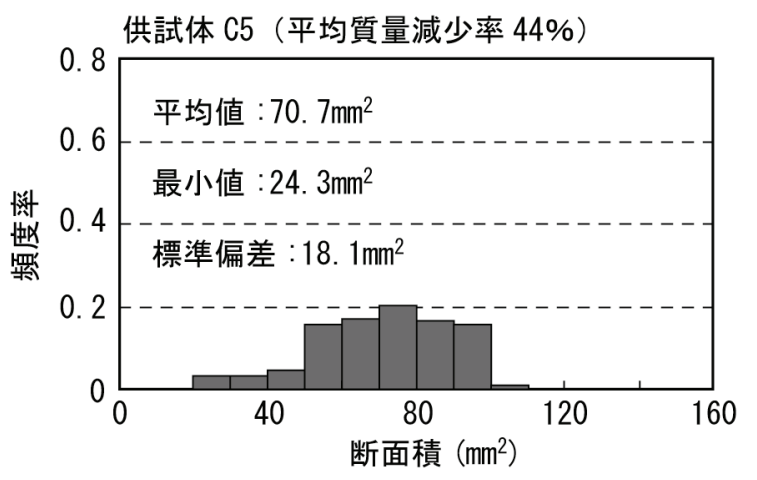

(b) 断面積のヒストグラム

図-12 腐食鉄筋の断面積分布の実測值 ${ }^{14)}$

鉄筋は，載荷の影響の少ないせん断スパン内から $400 \mathrm{~mm}$ の長さで取り出したもので，スキャナによる計測範囲は 鉄筋両端を除いた $360 \mathrm{~mm}$ である．腐食した鉄筋の外観目 視結果によれば，軸方向鉄筋の部位による腐食程度に大 きな違いはなく, 本供試体の軸方向鉄筋の腐食状況を代 表しているものとみなせる.

図-12（a)より，腐食した鉄筋の断面積が，鉄筋軸方向 に沿ってばらついているのが確認できる，鉄筋腐食のば らつきの影響を解析により評価する際に，実測された断 面積をそのまま用いることも考えられるが，本研究では より系統的に検討を行うために，腐食した鉄筋の断面積 分布を簡易な形でモデル化することとした.

岡崎ら ${ }^{10}$ は，電食により腐食させた鉄筋の断面減少量 を50mm間隔で測定して腐食量を算出し，腐食量の平均 值が大きくなっても軸方向分布の非一様性の程度はほぼ 一定であることを示している，具体的には，鉄筋の腐食 量が正規分布に従うものと仮定すると，腐食量が $10 \mathrm{mg} / \mathrm{mm}^{2}$ 程度までの範囲であれば，腐食量によらず変 動係数がほぼ 0.34 となることが報告されている. 本研究 では，図-13(a)に示すように，腐食した鉄筋の断面積分 布をサイン波を利用した周期的な分布としてモデル化を 行った. 図-13(b) は断面積分布を2周期としたものであ り, 図-13(c) はより実際の分布に近いランダムな分布と したものである. なお，図-13に示寸分布は，いずれも 平均質量減少率 $40 \%$ (平均腐食量 $9.97 \mathrm{mg} / \mathrm{mm}^{2}$ ) であり, 腐食量が正規分布に従うものと仮定した場合に，確率分 布の変動係数が 0.34 となるように断面積分布を設定した.

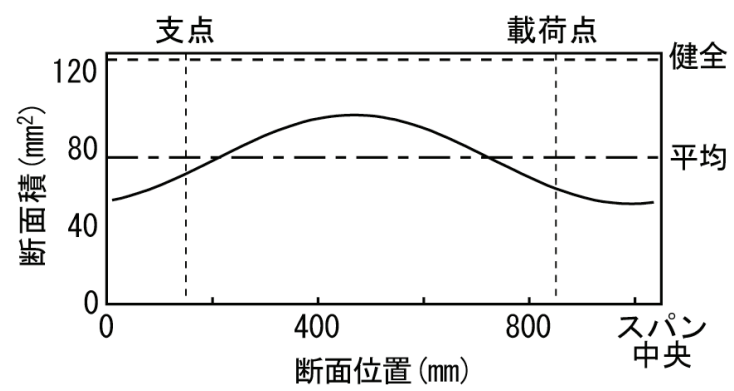

(a) サイン波を仮定した分布（1 周期）

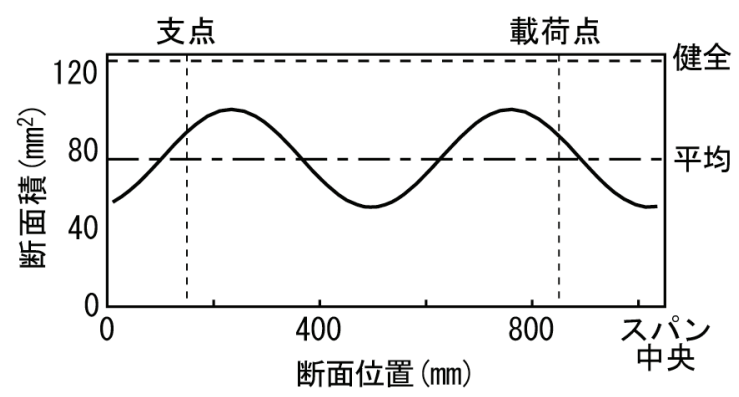

(b) サイン波を仮定した分布（2周期）

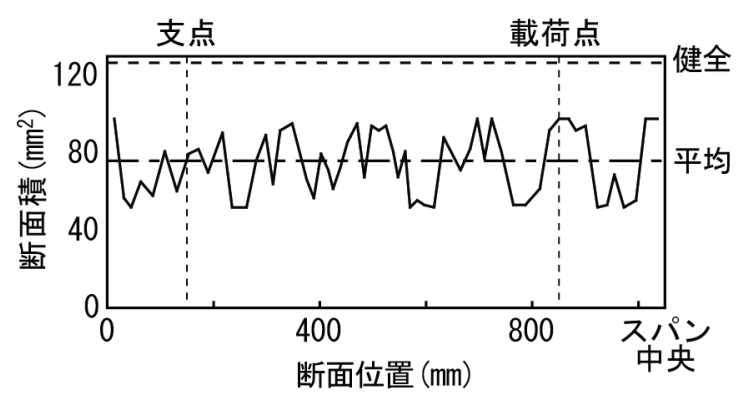

(c) ランダムな分布

図-13 仮定した断面積分布（平均質量減少率 40\%)

腐食量と断面減少率（質量減少率）は，次式 係付けた.

$$
\frac{A_{s}}{A_{s 0}}=1-\frac{4 w_{c}}{\rho_{s} \phi_{0}}
$$

ここに， $A_{s} / A_{s 0}$ は断面減少率， $w_{c}\left(\mathrm{mg} / \mathrm{mm}^{2}\right)$ は腐食量, $\rho_{s}$ は鉄の密度 $\left(7.85 \mathrm{mg} / \mathrm{mm}^{3}\right), \phi_{0}(\mathrm{~mm})$ は腐食前の鉄筋 の直径である.

図-13の分布における断面積の最小值はいずれも同じ 值 $\left(52.0 \mathrm{~mm}^{2}\right)$ であり，作用曲げモーメントが最大とな る等曲げモーメント区間に最小断面積が入るように設定 した．解析では，軸方向の鉄筋はり要素に対し図-13の ばらつきを考慮した断面積分布を適用し，耐荷性状への 影響が少ないせん断補强鉄筋は，軸方向鉄筋の平均質量 減少率となる一様な断面積とした.

図-14に，解析より得られた荷重一変位関係を示寸。サ 


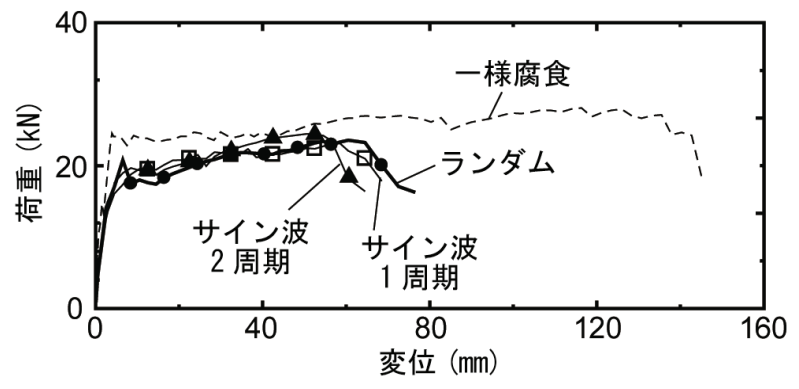

図-14 荷重-変位関係

イン波を仮定した分布とランダムな分布はいずれも平均 質量減少率40\%であるにも関わらず，質量減少率 $40 \%$ の 一様腐食よりも降伏荷重, 最大荷重, および変形性能が 低下している，これより，部材の耐荷性状は平均質量減 少率ではなく，断面積の最小值に依存していることが確 認できる．また，断面積が一様でない場合には，鉄筋と コンクリート間の付着性状も一様ではないため，ひび割 れがより局所的に進展しや寸く, 変形性能が低下寸る原 因となっている，サイン波を仮定した分布とランダムな 分布では，断面積の最小值は同じものの，鉄筋軸方向に 沿った付着のばらつきは異なってくる.しかしながら， 耐荷性状はほぼ同様の傾向を示しており，サイン波を仮 定した簡易な分布モデルでも，腐食のばらつきを考慮し た検討が可能であるものと考えられる.

実構造物では，より局所的な腐食が生じることが考え られるため，図-15に示寸ような局所的な腐食を考慮し た分布についても検討を行った．図-15(a) は一部の腐食 した区間を除いて健全な状態と仮定したものであり， 図-15 (b) は断面積の平均值が平均質量減少率 $40 \%$ となる ように仮定したものである，いずれも，最小断面積は 図-13の分布と同じ值とし，等曲げモーメント区間に入

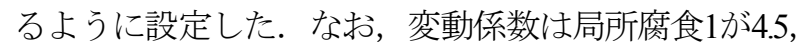
局所腐食 2 0.1 と，図-13の分布とは大きく異なる.

図-16に，解析より得られた荷重-変位関係を示す. 図 には，一様腐食を仮定した場合と，サイン波を仮定した 場合の結果も併せて示した。局所的な腐食を考慮した供 試体は，サイン波を仮定した分布と断面積の最小值が同 じであるため，降伏荷重はほぼ同等であるが，変形性能 に違いが現れた．局所腐食1は腐食部分の範囲外は付着 が良好であるため，鉄筋のひずみがより局所的に増大し たことによって，引張鉄筋の破断により早期に耐力低下 を起こした．また，最大荷重がサイン波やランダムな分 布を仮定したものより大きくなったのは，局所的な降伏 により降伏後の硬化の影響を大きく受けたためと考えら れる，つまり，局所的な腐食を考慮した場合には，降伏 位置での鉄筋ひずみがサイン波を仮定したものより大き

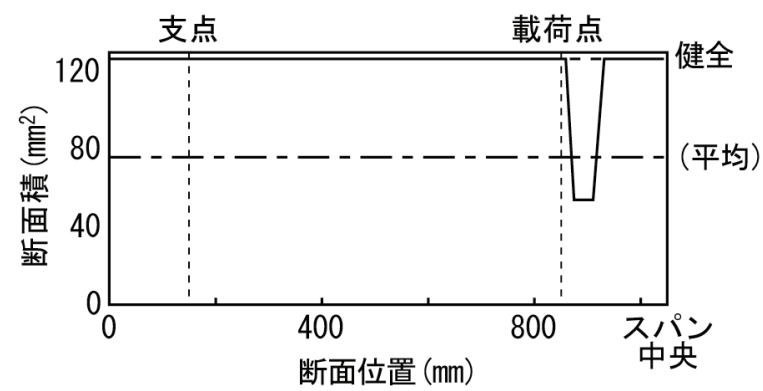

(a) 局所腐食 1

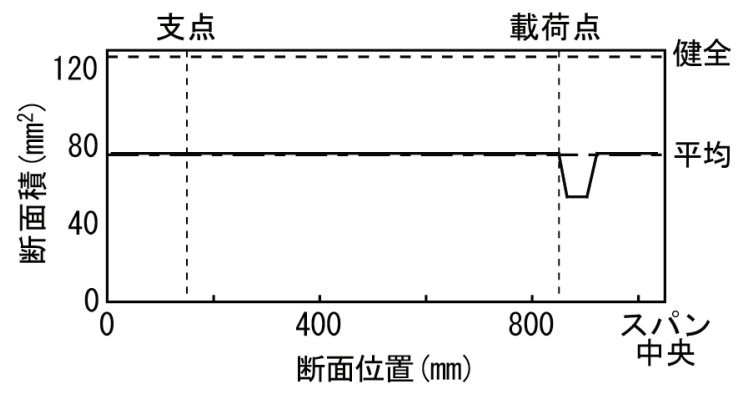

(b) 局所腐食 2

図-15 局所的な腐食を考慮した分布

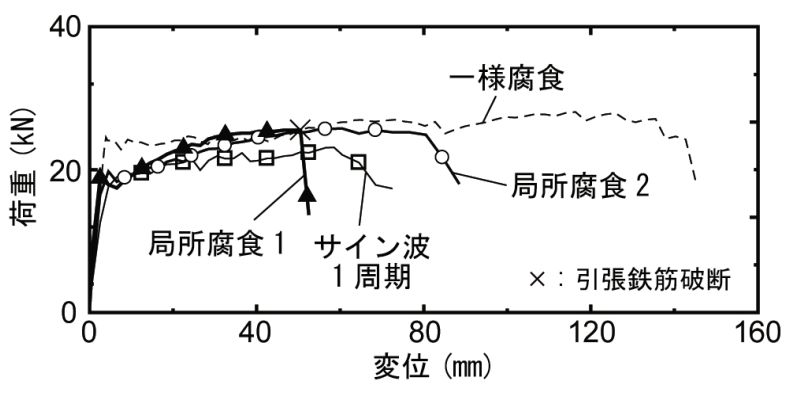

図-16 荷重-変位関係

くなり, 結果的により大きな応力を負担しているため耐 力が大きくなったものと考えられる，一方，局所腐食2 は腐食部分とその範囲外とで付着強度の差が小さく, 降 伏後は一様腐食に近い挙動を示した. ただし，本解析で は，圧縮鉄筋も引張鉄筋同様に局所的に腐食させている ため, 局所的な断面減少の影響を受けて比較的早期にコ ンクリートが圧壊し耐力低下を生じた.

以上の検討により，鉄筋の腐食分布を考慮したRCは り部材の降伏荷重は最小断面積の影響を大きく受け，最 大荷重や変形性能については付着強度のばらつきの影響 を受けることが確認できた．実際の腐食分布を忠実に再 現することにより精度の高い解析結果が得られるものと 考えられるが，簡易なサイン波を利用した解析でも耐荷 性状を概ね評価可能であるものと判断できる. 


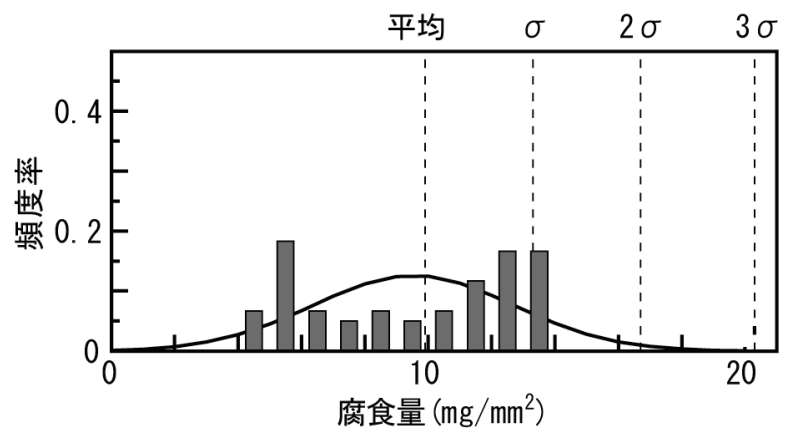

(a) 最大腐食量 $\sigma$

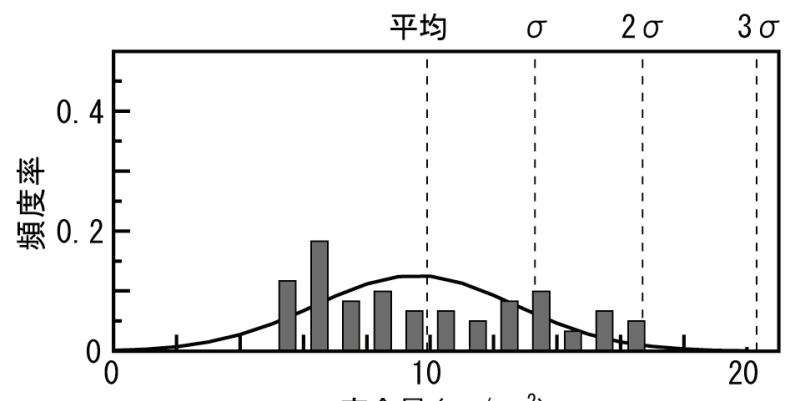

腐食量 $\left(\mathrm{mg} / \mathrm{mm}^{2}\right)$

(b) 最大腐食量 $2 \sigma$

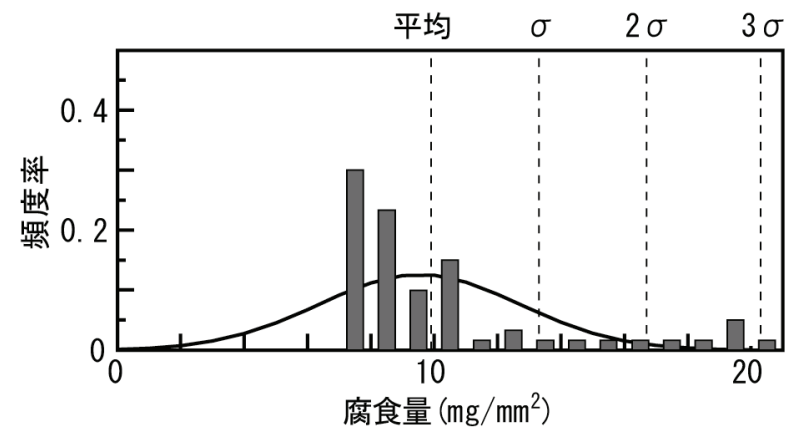

(c) 最大腐食量 $3 \sigma$

図-17 腐食量のヒストグラム (平均質量減少率 40\%)

\section{4. 最小断面積の大きさと位置が曲げ破壊性状に 及ぼす影響}

\section{(1) 解析概要}

前述の腐食のばらつきを考慮した解析では，一様腐食 を仮定した場合の結果より耐力が低下したものの，平均 質量減少率 $40 \%$ における耐力比は 0.6 程度で, 依然として 実験值（0.4程度）を過大評価している. 曲げ耐力は断 面積の最小值に大きく影響を受けることから，ここでは 最小断面積の大きさと位置が而荷性状に及ぼす影響につ いて検討を行った。

\section{(2) 最小断面積の大きさの影響}

図-13(a)に示した平均質量減少率40\%のサイン波1周期 の分布を基本とし，腐食量のヒストグラムが図-17とな るような分布を仮定した．変動係数が $0.34 て ゙$ 質量減少率 が40\%となるには，腐食量の平均值が $9.97 \mathrm{mg} / \mathrm{mm}^{2}$, 標準

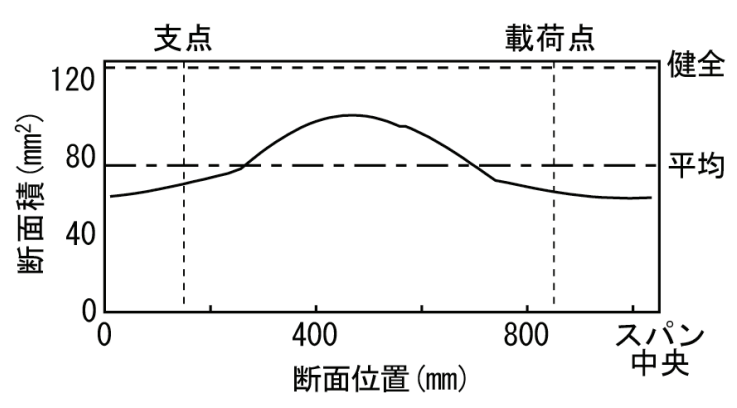

(a) 最大腐食量 $\sigma$

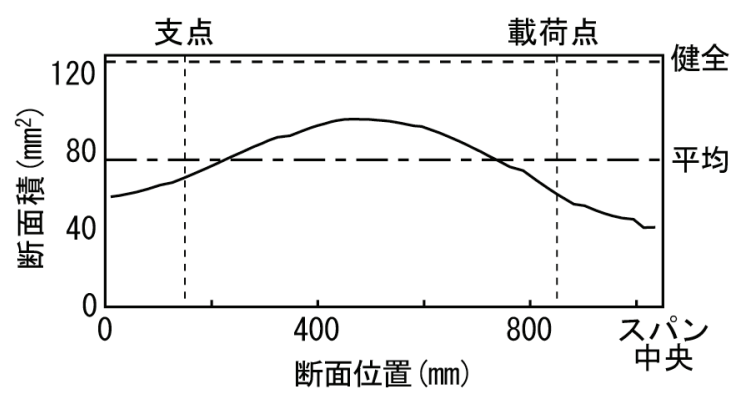

(b) 最大腐食量 $2 \sigma$

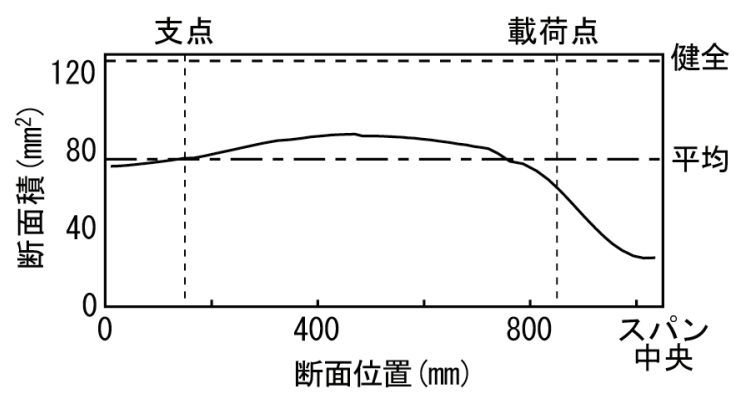

(c) 最大腐食量 $3 \sigma$

図-18 断面積分布（平均質量減少率 40\%)

偏差 $(\sigma)$ が3.39 mg/mm 2 となる. 分布の作成方法は次 のとおりである.まず，図-13(a)に示した平均質量減少 率 $40 \%$ のサイ波 1 周期の分布をベースに，等曲げモー メント区間における最大腐食量がそれぞれ $\sigma, 2 \sigma$, $3 \sigma$ だけ離れた值となるように設定した，その後，腐食 量のヒストグラムが平均質量減少率が $40 \%$ で変動係数が 0.34となるようにサイン波を調整した。 得られた断面積 分布が図-18であり, この分布の腐食量のヒストグラム が図-17である. サイン波1周期を基本としているため, 最大腐食量が大きくなるほど局所的に大きな腐食を持つ ような分布となり，最小質量減少率は，それぞれ $53 \%$, $68 \%$ ，80\%となる.

図-19は，解析により得られた荷重一変位関係である. いずれの分布も最小断面積が平均值よりも小さいため, 降伏荷重および最大荷重が一様腐食を仮定した解析より 低下しているのが確認できる. 最小断面積が小さくなる ほど降伏荷重および最大荷重が低下し，耐力が最小断面 


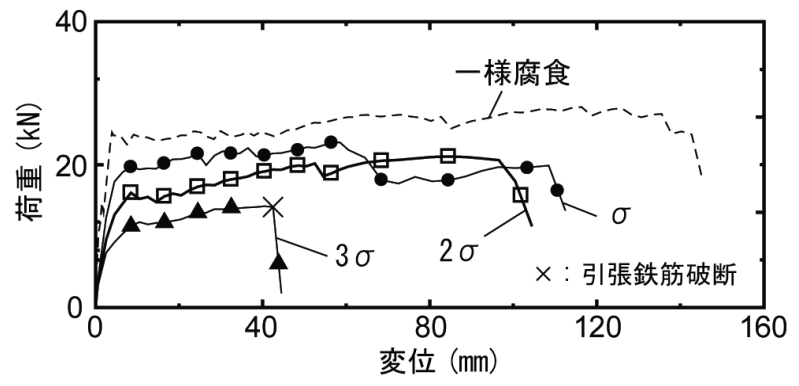

図-19 荷重-変位関係

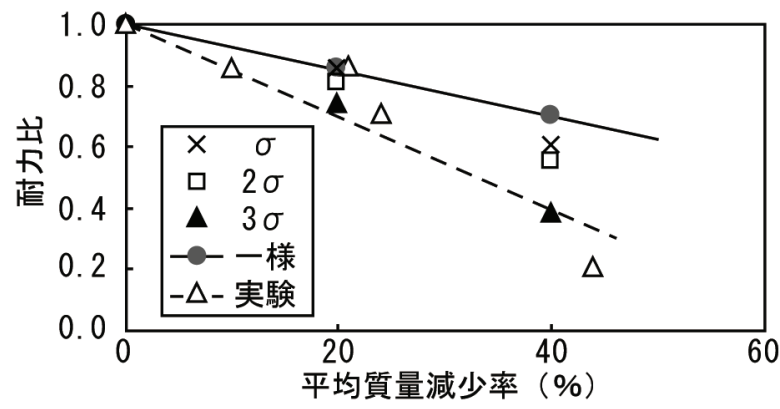

図-20 曲げ而力比と平均質量減少率

積に依存していることが分かる．また，最大腐食量が $3 \sigma$ だけ離れた分布では引張鉄筋の破断が生じ，著しく 変形性能が低下していることが確認できる.

図-20に，実験および解析より得られた曲げ耐力比と 平均質量減少率の関係を示寸，平均質量減少率 $20 \%$ につ いても同様の解析を行った．耐力比は，それぞれ健全な 供試体の耐力を 1.0 とした。図より，平均質量減少率が 増加するほど解析より得られた耐力のばらつき（一様腐 食を仮定した解析結果からの偏差）が大きくなることが 確認でき，実験值のばらつき（一様腐食を仮定した解析 結果からの偏差）の範囲にほぼ対応している．本解析の 範囲においては，腐食量が変動係数を 0.34 とした正規分 布に従うものと仮定した場合，平均腐食量に対して最大

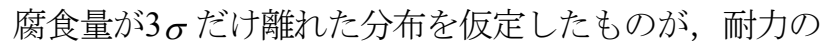
ばらつきの下限值になるものと考えることができる．な

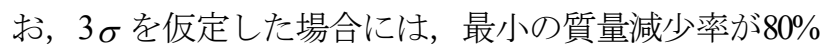
に達するが，耐力比は 0.4 程度までしか低下していない． これは，降伏荷重は健全な場合の10\%程度まで低下する ものの, その後, 引張鉄筋のひずみが局所的に増大し, 硬化により鉄筋応力が増大寸るため，見かけの耐力が大 きくなったことによる.

曲げ耐力比を $r$, 平均質量減少率を $\bar{C}(\%)$ とし, 両者 に次式のような直線関係があるものと仮定する.

$$
r=-k(\bar{C} / 100)+1.0
$$

ここに， $k$ は直線の傾きである.

実験結果を回帰寸ると $k$ は1.57で1を超過しており，質 量減少率以上に曲げ耐力が低下寸ることを示している.

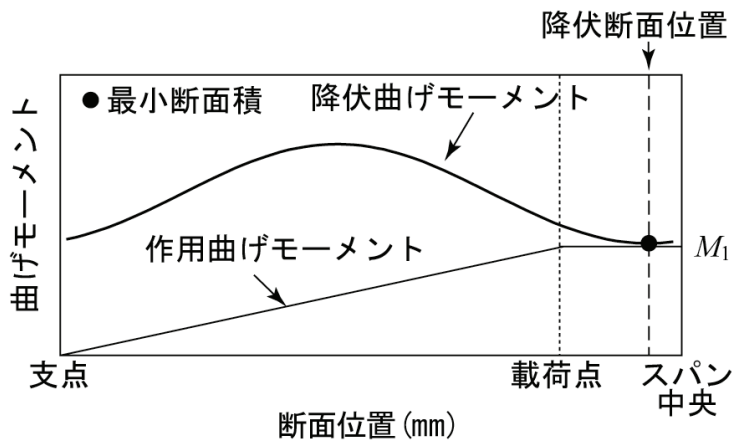

(a) 最小断面積が等曲げモーメント区間内にある場合

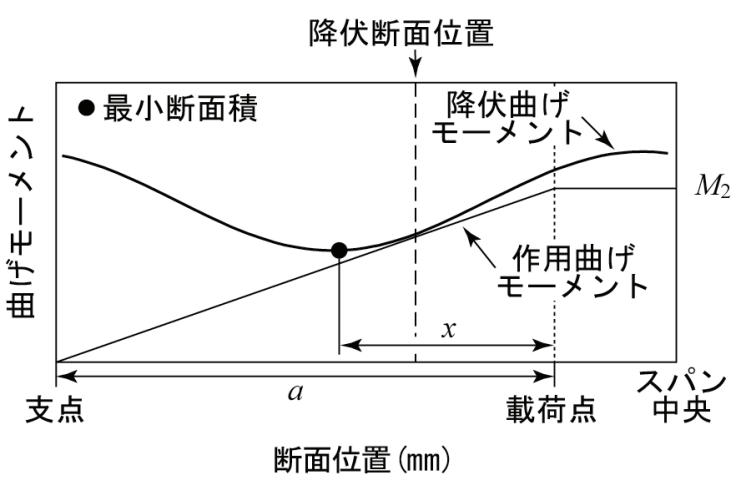

(b) 最小断面積が等曲げモーメント区間外にある場合

図-21 最小断面積の位置と降伏断面位置の関係

一様腐食を仮定した解析では $k$ は 0.75 となり, 実験結果 をかなり過大評価する結果となる。一方, 最大腐食量を $3 \sigma$ とした解析では $k$ は 1.51 となり, 実験結果とほぼ対応 している.

\section{(3) 最小断面積の位置の影響}

これまでの解析では，作用曲げモーメントが最大とな る等曲げモーメント区間に最小断面積が入るように分布 を仮定してきた．図-21に示すように，同じ周期と変動 係数を仮定した分布でも，最小断面積の位置が部材軸方 向に変化すると, 最初に鉄筋が降伏する位置が変化し, 降伏荷重や曲げ耐力が変化することが考えられる，そこ で，最小断面積の位置が耐荷性状に及ぼす影響について 検討を行った，解析は，変動係数を 0.34 で一定とし，サ イン波1周期を仮定した分布に対して，最小断面積の位 置が等曲げモーメント区間にある場合，等曲げモーメン 卜区間外の載荷点寄りにある場合，等曲げモーメント区 間外の支点寄りにある場合について行った，図-22は， 仮定した断面積分布である. なお，最小断面積がせん断 スパン内にある場合には，その付近のせん断補強鉄筋の 腐食程度も大きくなることが予想されるが，前述のとお り, 本供試体の諸元ではせん断破壊を生じる可能性が低 いことから，せん断補強鉄筋には質量減少率 $40 \%$ の一様 な腐食を仮定した. 


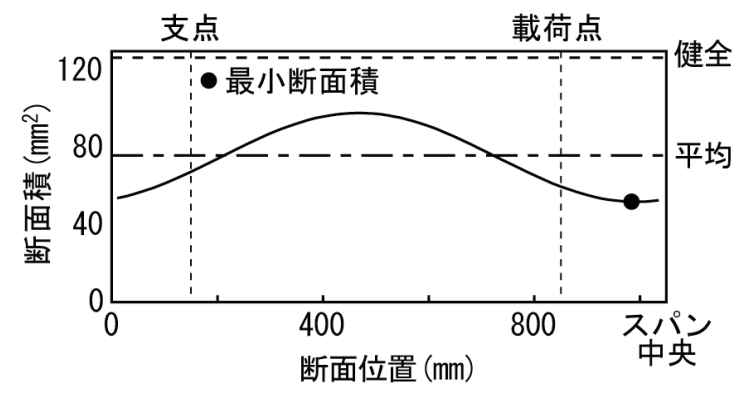

(a) 最小断面積が等曲げモーメント区間内

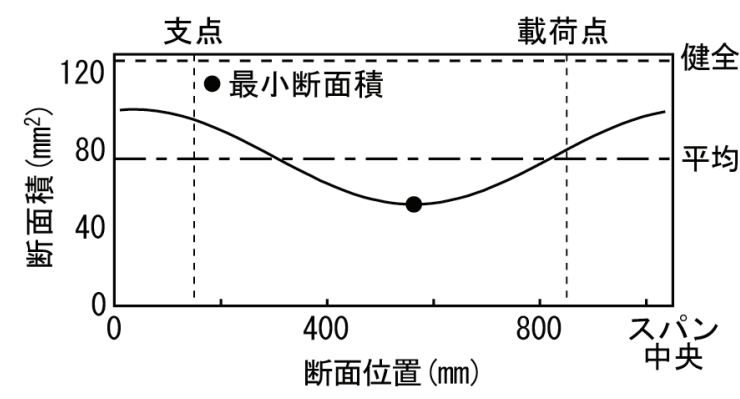

(b) 最小断面積が等曲げモーメント区間外 (載荷点寄り)

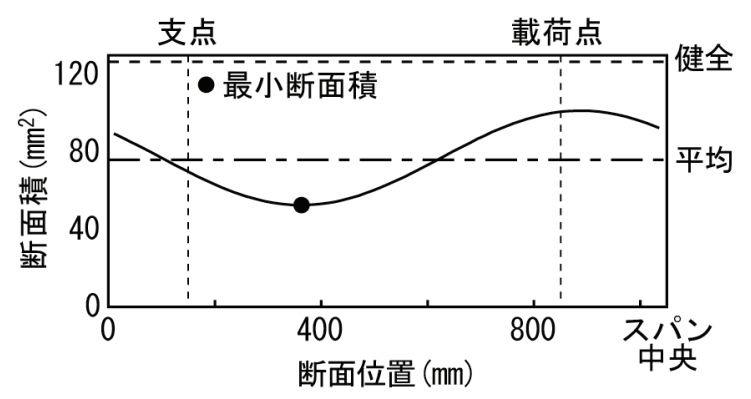

(c) 最小断面積が等曲げモーメント区間外（支点寄り）

図-22 断面積分布

図-23に，解析より得られた荷重一変位関係を示す. 図-21の概念困から明らかなように，最小断面積の位置 が等曲げモーメント区間内にある場合が降伏荷重および 最大荷重が最も小さくなる.

図-24に，解析により得られた降伏荷重時のひび割れ 性状を示す。また，図-25に，降伏荷重時の引張鉄筋の ひずみ分布を示す，最小断面積が等曲げモーメント区間 外にある場合で，図-22(b)のように載荷点寄りの分布を 仮定した場合は，最小断面積の位置に近い場所で鉄筋の ひずみが増大し破壊に至った。一方，図-22(c)のように 支点寄りの分布を仮定した場合には，最小断面積の位置 よりも，作用曲げモーメントが最大となる等曲げモーメ ント区間で鉄筋のひずみが増大するようになる。つまり， 最小断面積の位置が等曲げモーメント区間からある程度 離れると，最小断面積の位置によらず等曲げモーメント 区間で鉄筋が降伏し破壊に至る。ただし，いずれの場合 も最小断面積の位置が等曲げモーメント区間内にある場

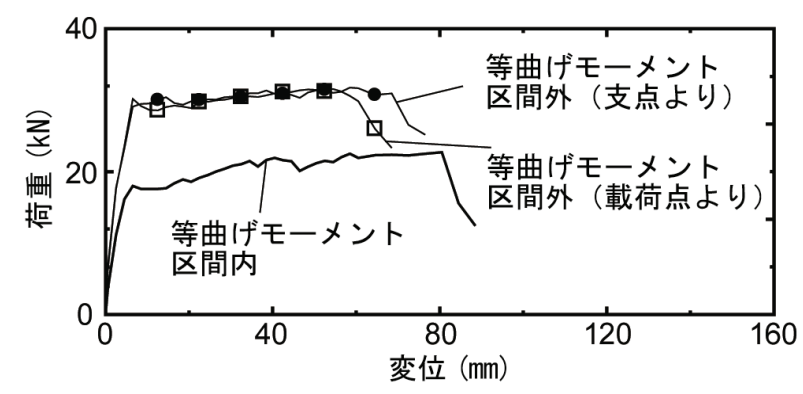

図-23 荷重-変位関係

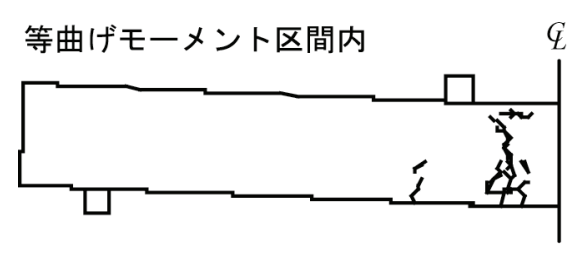

等曲げモーメント区間外 (載荷点より)

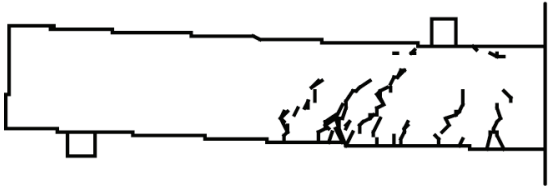

等曲げモーメント区間外 (支点より)

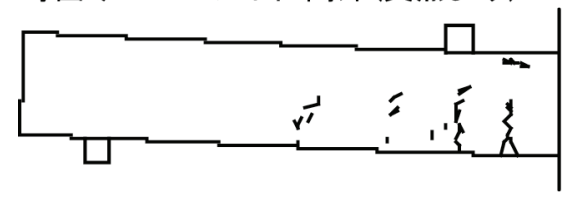

図-24降伏時のひび割れ性状

合よりも降伏荷重および最大荷重は大きくなることが確 認できる.

図-21に示す概念図において，せん断スパンを $a ，$ 最 小断面積が等曲げモーメント区間内にあるときの降伏曲 げモーメントを $M_{1}$ とすれば，図の幾何学的関係より， 最小断面積が載荷点から $x$ だけ離れた位置にあるときの 降伏曲げモーメント $M_{2}$ は, 次式で求められる.

$$
M_{2}=M_{1} \frac{a}{a-x}
$$

ただし，上式は作用曲げモーメントが降伏曲げモーメン 卜の頂点と接するものと近似した場合である。図-21 (b) のようにサイン波1周期を仮定した場合には，作用曲げ モーメントと降伏曲げモーメントの接する位置は頂点か らずれてしまうが，実際の分布に近い図-13(c)のような 周期の短い分布では，ずれの影響は小さくなるため，本 式により十分評価は可能である.

図-26に，降伏荷重と降伏断面の載荷点からの距離の 関係を示す．図-22に示す分布に加えて，図-13(b)に示 すようなサイン波で2周期を仮定した分布についても同 様の解析を行った。 図中のプロットは, 最小断面積が等 曲げモーメント区間内にある場合がA，等曲げモーメン 


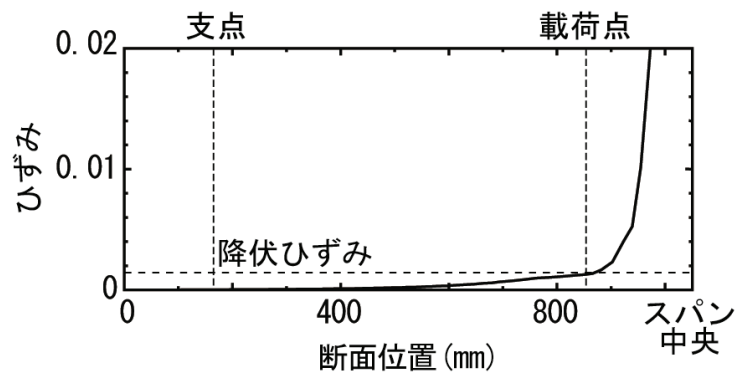

(a) 最小断面積が等曲げモーメント区間内

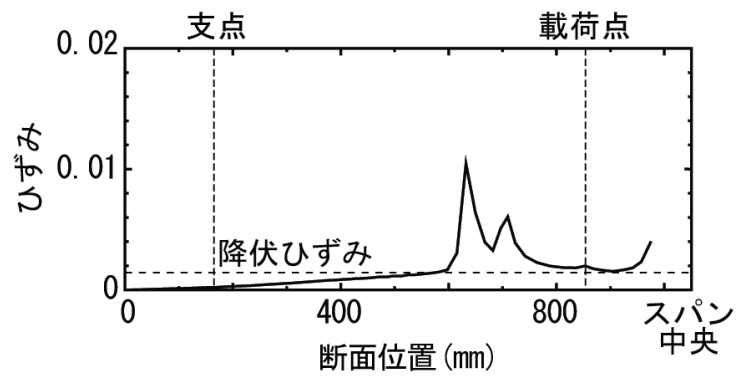

(b) 最小断面積が等曲げモーメント区間外（載荷点寄り）

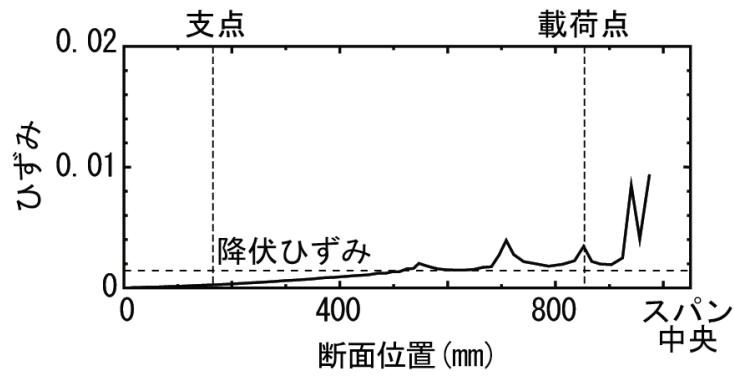

(c) 最小断面積が等曲げモーメント区間外（支点寄り）

図-25降伏時の引張鉄筋のひずみ分布

卜区間外で載荷点寄りにある場合がB，支点寄りにある 場合がCである．最小断面積が等曲げモーメント区間内 にある場合が降伏荷重の最小值となる（図中のA）。図 中のBのように, 最小断面積の位置が載荷点から離れる につれて降伏位置もせん断スパン内に移行し，降伏荷重 も大きくなることが確認でき，この傾向は式(4)によっ て概ね評価できることが分かる．また，図-22(c)の分布 のように, 最小断面積の位置が載荷点からある程度離れ ると，最小断面積の位置ではなく，図中のCのように等 曲げモーメント区間内で降伏するようになる.

\section{5. 結論}

鉄筋の腐食分布が曲げ破壊するRCはり部材の耐荷性 状に及ぼす影響について，解析的に検討を行った．本検 討では，鉄筋腐食の影響は断面積の減少之付着強度の低 下により考慮し，腐食ひび割れによるコンクリートの損

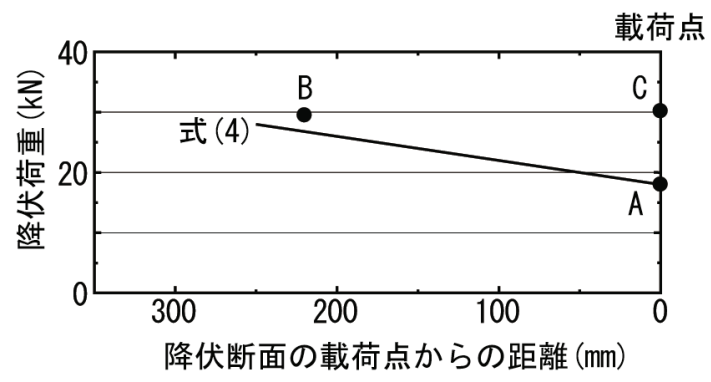

(a) サイン波 1 周期

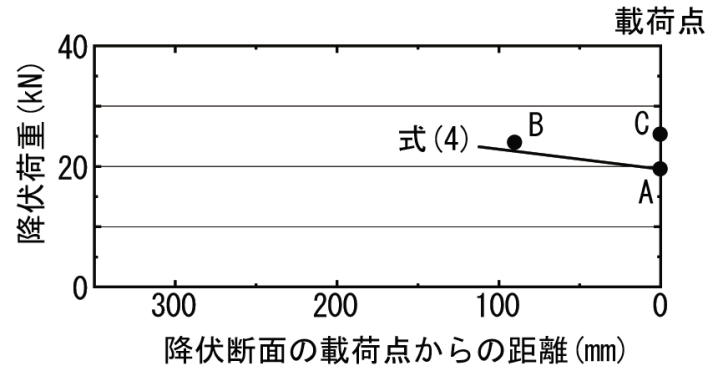

(b) サイン波 2 周期

図-26 降伏荷重と降伏断面位置の関係

傷は無視している．また，解析における鉄筋の腐食分布 のモデル化は，電食試験の結果を参考とした．以上の前 提の下に検討を行った結果，得られた知見は以下のとお りである。

(1) 鉄筋腐食の生じた曲げ破壊するRCはり部材の降伏荷 重や最大荷重は, 最小断面積の大きさに影響を受ける. 一方，変形性能は腐食程度が大きくなると向上する傾向 にあるが，付着劣化状態の影響を大きく受ける. 特に, 局所的に腐食が生じている場合のように付着劣化領域が 狭い場合には，鉄筋の変形が局所化するために破断が生 じ易くなり, 最大荷重や変形性能はともに著しく低下寸 る恐れがある。

（2）腐食量が正規分布に従うものと仮定した場合，降伏 荷重や最大荷重のばらつきは，一様腐食を仮定した場合 の結果と最大腐食量が平均值から $3 \sigma$ だけ離れた場合の 結果との間にほぼ収まる。したがって, 腐食量の平均值 と変動係数が得られれば，鉄筋腐食の生じたRCはり部 材に対し，曲げ耐力のばらつきの範囲を概ね推定するこ とができる.

（3）最小断面積の位置によって, 降伏断面の位置や降伏 荷重は変化するが，最小断面積が作用曲げモーメントが 最大の位置にある場合に降伏荷重は最小值となる。

謝辞：本研究の一部は，文部科学省科学研究費補助金 （若手研究（B）19760313）の助成により実施した。本 論文の作成に際しては，土木学会コンクリート委員会 「材料劣化が生じたコンクリート構造物の構造性能小委 
員会」（委員長・下村匠 長岡技術科学大学准教授）の 委員諸氏に多大なるご協力をいただきました．また，論 文に用いたデータの作成に関しては, 山梨大学卒業生の 横山友美嬢および寺田文治氏にご協力をいただきました. ここに記して謝意を表します。

\section{参考文献}

1)土木学会 : コンクリート標準示方書 [維持管理編 $], 2007$.

2) 李翰承，野口貴文，友澤史紀 : 引張鉄筋の腐食した RC 梁の 有限要素法による耐力性能評価に関する基礎的研究，日本 建築学会構造系論文集, No.506, pp.43-50, 1998.

3) 松尾豊史, 松村卓郎, 遠藤達巳, 橘泰久 : 強制的に腐食させ た RC ボックスカルバートの載荷実験シミュレーション，コ ンクリート工学年次論文集, Vol.24, No.2, pp.1297-1302, 2002.

4) 橋本航，森川英典，小林秀惠 : 鉄筋腐食を考慮した RC はり 部材のせん断而荷性能評価，コンクリート工学年次論文集, Vol.25, No.2, pp.1009-1014, 2003.

5) Coronelli, F. and Gambarova, P. : Structural assessment of corroded reinforced concrete beams : modeling guidelines, Journal of Structural Engineering, ASCE, Vol.130, No.8, pp.1214-1224, 2004.

6) Toongoenthong, K. and Maekawa, K. : Multi-mechanical approach to structural performance assessment of corroded $\mathrm{RC}$ members in shear, Journal of Advanced Concrete Technology, Vol.3, No.1,pp.107-122, 2005.

7) 日本コンクリート工学協会 : コンクリート構造物のリハビリ テーション研究委員会報告書, 1998 .
8) 日本コンクリート工学協会 : コンクリート構造物の長期性能 照査支援モデルに関するシンポジウム, 2004

9) 土木学会 : 材料劣化が生じたコンクリート構造物の構造性能, コンクリート技術シリーズ 71，2006.

10) Kawai, T. : New discrete models and their application to seismic response analysis of structure, Nuclear Engineering and Design, Vol.48, pp.207-229, 1978.

11) Saito, S. and Hikosaka, H. : Numerical analyses of reinforced concrete structures using spring networks with random geometry, Journal of Materials, Concrete Structures, and Pavements, JSCE, No.627/V-44, pp.289-303, 1999.

12) 斎藤成彦，中村光，檜貝勇 : 剛体一バネモデルを用いた RC パネルのせん断二次破壊に関する解析的研究，土木学会論 文集，No.704/V-55，pp.219-234， 2002.

13) 菅満宣, 中村光，檜貝勇，斉藤成彦：RCはりの力学的挙動 に及ぼす付着特性の影響, コンクリート工学年次論文集, Vol.23, No.3, pp.295-300, 2001.

14) 大屋戸理明, 金久保利之, 山本泰彦, 佐藤勉 : 鉄筋の腐食 性状が鉄筋コンクリート部材の曲げ性状に与える影響，土 木学会論文集 E, No.62, No.3, pp.542-554, 2006.

15) 土木学会 : コンクリート標準示方書 [設計編]， 2007.

16) 岡崎雅弘, 下村匠，松尾洋 : 鉄筋軸方向の非一様性に着目 したコンクリート中の鉄筋腐食と腐食ひび割れ幅に関する 検討, コンクリート工学年次論文集, Vol.25, No.1, pp.857862, 2003.

(2008.4. 21 受付)

\title{
INFLUENCE OF CORROSION DISTRIBUTION OF STEEL REINFORCING BARS ON FLEXURAL BEHAVIOR OF REINFORCED CONCRETE BEAMS
}

\author{
Shigehiko SAITO, Ryosuke TAKAHASHI and Takeshi HIGAI
}

This paper presents numerical studies on influence of corrosion distribution of steel reinforcing bars on flexural behavior of reinforced concrete beams. Steel corrosion is modeled by reducing cross sectional areas of reinforcement elements and bond strength of linkage elements according to corrosion levels. Corrosion distribution of steel reinforcing bars is assumed as a simple sine curve, and its property is decided by an average corrosion weight loss and a coefficient of variation. The flexural capacity of reinforced concrete beams with steel corrosion depends on the minimum cross sectional area of steel bars, and the ductility of beams is influenced by the condition of bond deterioration. 